\title{
Where Oil Occurs
}

\section{A Brief Description of the Rocks and Sands in Which Petroleum Is Found}

\author{
By C. H. Messerly
}

F XPERIENCE has taught us that oil does exist, E and that it is found in formations or reservoir rocks known as sand, sandstone, limestone, etc., and that commercial deposits generally occur in the higher parts of folds of the earth's surface, called anticlines, domes, monoclines, etc. Water is generally found in the same stratum as the oil, but in the lower part of the fold. Oil, being lighter, is found next above, and gas, being still lighter, in the top. Some authorities say that oil is generated in underlying strata and has migrated through the different formations and crevices to these reservoirs, which are capped or covered by practically impervious beds of shale, sandstone or limestone, most frequently shale. The action of this cap stone, most frequently shale. The action of this cap
rock is to prevent the oil from leaking away to the rock is to prevent the oil from leaking away to the
surface and disappearing. This is what must have happened in some fields from which the oil has vanished.

One of the most widespread formations overlying gas and oil sands is the Utica shale above the Trenton limestone in the Ohio and Indiana fields. The Clinton sand of central Ohio is overlaid by the Clinton shale. The oil sands of Pennsylvania and West Virginia are all overlaid by impervious shales. In Louisiana fields a hard stratum of limestone sometimes acts as a cap rock overlying a more pervious portion of the same formation.

The porosity or capability of sandstone and sands to hold oil is due to the shape and arrangement of the grains. In the case of sandstones, the occurrence of oil is due not only to structure, but is affected also by the continuity of the stratum. Drillers recognize the internal variations when they speak of a sand being open or close, soft or hard and good or poor in character. The question of the amount of oil which a certain formation can contain in view of its porosity is a rather complicated subject. The texture of the sand is of supreme importance. Sandstones and shales often carry oil, but they are not the most favorable reservoirs, since in most sandstones the cementing material binding the sand grains together fills the pores so that the rock can hold only a small quantity of fluid.

The percentage of voids in the various kinds of strata varies considerably. Sands may contain from 15 to 35 per cent voids; sandstones 5 to 15 per cent; conglomerates as high as 30 per cent; shale from 2 to 10 per cent; and some dolomitic limestones are reported to contain as high

as 35 per cent. The percentages are so variable that one cannot take the material in one field to be a criterion or measure of material in other fields.

The quantity of oil in sands depends on the percentage of voids in the sand and its saturation, by which is meant the percentage of oil present by volume in a cubic foot of sand. We are told that some sands contain 20 per cent voids, and if those voids were full, the saturation would be 20 per cent, hence 100 cubic feet of sand would contain 20 cubic feet of oil. The United States Government, in its estimates of oil reserves, takes 10 per cent as the saturation. For example: A bed 100 feet thick and covering an acre of land would contain (42 gallons per barrel-7.5 gallons per cubic foot) $\mathbf{7 7 , 7 8 6}$ barrels. It is estimated that the porosity of the Appalachian field is $\mathbf{1 2 . 5}$ per cent; of the Illinois and Mid-Continent field $\mathbf{1 7 . 5}$ per cent, and of the California field 25 per cent.

It is a well-known fact that the quality of crude petroleum is determined by the impurities contained therein. As an illustration it may be cited that Lima Ohio, oil contains about .75 per cent sulfur and that Pennsylvania oil contains only about .03 per cent. Because of these impurities and the greater cost of refining, the price also varies.

I cannot find any scientific theory for the fact that more impurities are contained in the oils of some fields than in others, but it is possible these may have been picked up in its migratory process, rather than from picked up in its migratory process, rather
the sand where the oil happens to be found.

The specific gravities of petroleum have also been used as rough measurements, of its value. The lighte the oil, the better it is generally considered. An oil with a specific gravity of 40 degrees will generally produce more of the valuable by-products than one of 15 degrees.

One author says the difference in specific gravity is due to migration, or travel from one formation to another. Another that it is due to age, the heavier ils occurring in formations that are much younger than those containing lighter oils, although it is stated there are exceptions to this rule.

In conclusion, or as your parson would say, "Lastly," it might be of interest to group the oil pools of the United States into fields. The most important of these are the Appalachian, Lima-Indiana, Illinois, Mid-Continent, Gulf Coast, California, Colorado and Wyoming.

The Appalachian field covers a very large area, but it is no longer the most important in quantity of production, although it continues to hold first place in quality. It embraces all oil pools east of central Ohio, in cluding New York, Pennsylvania, West Virginia, southeastern Ohio, Kentucky and Tennessee. With the exception of that from Kentucky and Tennessee most of this oil is considered Pennsylvania grade, free from objectionable sulfur and from asphalt, and rich in paraffin.

The Lima-Indiana field comprises Western Ohio and Indiana. The petroleum in this field was found in the Trenton limestone, contains little asphalt but is contaminated with the objectionable sulfur compounds.

The Illinois field is located in the state bearing its name, the main portion of which is associated with a structural feature known as the La Salle anticline, extending from the northeastern part of the state into southwestern Indiana. The petroleum is thick, asphaltic, and contains sulfur in the northern portion, but in the southern part of the field it is found at a greater depth, is thinner and contains little or no sulfur. The Mid-Continent field includes the oil pools of Kansas, Oklahoma, Caddo, De Soto, Louisiana, and northern

eastern oil fields we find the second and third sands of Oil Creek, Pennsylvania; the second, Tioga and Bradford sands of northwestern Pennsylvania; the Waugh \& Porter and Richburg sands of western New York; the 100-Foot, third and fourth sands of Butler County Pennsylvania; the Salt sand, Maxom, Big Injun, Gor don and fifth sands in West Virginia; and the Cow Run, Berea, Clinton and Trenton sands of Ohio. In Illinois the Casey, Robinson, Bridgeport, Kirkwood and McClokley are well known; and in Oklahoma there are a number of different producing sands, the Bartlesville being the most extensive. In the Gulf Coast, Louisiana and Texas fields, the sands occur more in irregular lenses and the production is in pools.

\section{Reducing Noise in Factories}

M ANY authorities believe that loud and continuous system, and are responsible for much of the nervous disturbance and maladies of the nerves, which are, apparently, on the increase among dwellers in the cities. Even when the victim is so habituated to the noise which surrounds him as to be hardly conscious of it the noise may, nevertheless, exert a deleterious effect. In a recent number of a German technical magazine, an engineer named Walter Ritter, has suggested certain methods for reducing the inescapable noise in factories, machine works, mines, etc, to the lowest possible minimum. His basic idea is that it is less important to reduce the actual noise than to check the spread of the vibration to which the noise is due, since in his opinion it is such vibrations that chiefly affect the nerves, having a more injurious effect than the pounding of a steam hammer or the buzzing of a motor.

The first law he lays down is that the foundation upon which a piece of machinery is erected must be absolutely solid and resistant to pressure, and he suggests that a suitable material for making such foundations is armored cement or else a masonry of slag set in mortar of pure cement. However, this foundation does not lessen the noise, since each of the two materials suggested is an excellent conductor of sound. One or the other of these materials is essential because of the firmness and solidity, but Mr. Ritter suggests the mixing of the cement with quartz sand and finally cement with. quartz sand and finally
broken stones to form a sheet 10 centimeters in thickness as the first layer of the foundation. Upon this are placed successive layers having a slightly different

Texas. The petroleums of this field vary in composition within wide limits. Most of the Kansas oils are asphaltic, but in Oklahoma petroleum of both paraffin and asphalt base are found. The crude petroleum of the Healdton field in Oklahoma is of lower grade than the crude oils from the Glenn pool and Cushing field on account of the lower gasoline content and the large percentage of sulfur present. In northern Louisiana and Texas paraffin base petroleums, free from sulfur, predominate, but asphaltic oils of higher gravity have also been found.

In the Gulf Coast are included a number of areas lying in the coastal plain region, the pools of southern Texas and southern Louisiana. The oils have been found in association with salt domes, which also carry limestone and gypsum. They are usually heavy, asphaltic and sulfurous, but occasionally lighter, nonasphaltic ones also occur.

In the California field the petroleums have been usually characterized by much asphalt, although in recent vears lighter oils have been found.

In the Colorado field a high-grade, lfght illuminating oil is found in Boulder County, a lubricating oil in Routt County, etc.

The Wyoming field is one of the newest, the oil in Big Horn County being a heavy, black asphaltum oil. In other places oil

Although new producing formations are constantly being developed, in almost every oil field of any size or age there has been found one or more sand strata that stand out prominently because of the thickness of their "pay streaks" and producing qualities: these strata are used for purposes of comparison, values being frequently based upon their past history and production per acre over a given period of time. In the composition, gray lime and kieselguhr, each layer being firmly connected with the one below. The uppermost layer which should be from 10 to 20 centimeters thick should consist of kieselguhr cement. A foundation built in this manner possesses the property of deadening sound considerably and also reduces the vibration since the use of the kieselguhr has the effect of imparting elasticity to the cement.

Vibration is further reduced by means of an insulating material. Rubber might be considered best for this purpose, but rubber does not assist in lessening the noise. The best material for laying under the machine has been found by experiment to be a thick wool felt, the so-called iron felt with an impregnated surface or crust. Such felt exhibits great resistance to pressure combined with a high degree of elasticity. It has been shown by experiment that this felt is not "deformed" by loads up to a pressure of 1450 atmospheres. Such favorable results have been obtained by this method of constructing machine foundations that it is to be expected their use will be rapidly extended.

\section{Electronic Classification of the Elements}

DUVILLIER, in Revue Générale de l'Electricité, due chiefly to the uf $\mathrm{X}$-rays, and makes special reference to the formula published by Moseley and the subsequent classification of substances by numbers irrespective of atomic weight, etc. He discusses very fully the electronic structure of atoms and molecules as discovered and published by numerous investigators. The elements are then tabulated in a table having eight vertict columns, representing chemical valency, and eleven horizontal columns representing the number of layers of electrons. 